Ewa Domagała-Zyśk

Katolicki Uniwersytet Lubelski Jana Pawła II

\title{
KOMPETENCJE UCZNIÓW \\ NIESEYSZĄCYCH \\ I SŁABOSŁYSZĄCYCH \\ W ZAKRESIE POSŁUGIWANIA \\ SIĘ JĘZYKIEM ANGIELSKIM \\ W SZKOLACH PODSTAWOWYCH, GIMNAZJACH I SZKOLACH PONADGIMNAZJALNYCH
}

\section{Deaf and hard of hearing students' competencies in using \\ English as a foreign language in primary, low secondary and secondary schools}

Teaching foreign languages to the deaf formally started in Poland in 2001 so it still can be treated as a relatively new educational phenomenon that needs to be thoroughly researched. So far there have been only several works in the literature that would present the approaches, methods and techniques that the teachers might use. However, there is not a single study that would touch upon the problem of the effectiveness of the teaching programs. The aim of the paper is to explore the linguistic competencies of the deaf students of Polish primary, low secondary (gymnasium) and secondary schools as far as their reading comprehension, vocabulary and grammar competencies and communicative skills are concerned. On the basis of these analyses and contemporary knowledge about the principles of teaching foreign languages to the deaf (cf. Domagała-Zysk 2001, 2003, 2010 and others) a document is presented, Linguistic competences of the hearing-impaired students in the foreign language classroom, that might serve as a significant contribution to our knowledge about the effectiveness of foreign language education for deaf students. 


\section{Wstęp}

Nauczanie języków obcych uczniów niesłyszących w Polsce formalnie zostało uregulowane Rozporządzeniem MEN z dnia 21 maja 2001 roku w sprawie podstawy programowej wychowania przedszkolnego, kształcenia ogólnego w poszczególnych typach szkół oraz kształcenia w profilach w liceach profilowanych (Dz. U. Nr 61, poz. 625), które określa cele edukacyjne w nauczaniu języków obcych dla poszczególnych typów szkół, oraz Rozporządzeniem MEN z dn. 21 maja $2001 \mathrm{w}$ sprawie ramowych programów nauczania w szkołach publicznych (Dz. U. Nr 61, poz. 626). Rozporządzenia te ustalają iż dla uczniów szkół specjalnych dla niesłyszących i słabosłyszących obowiązkowe staje się nauczanie języka obcego na poziomie szkoły podstawowej (od drugiego etapu nauczania, tzn. począwszy od klasy IV), gimnazjum i liceum. Zgodnie z Rozporządzeniem MEN z dnia 21 marca 2001 w sprawie warunków i sposobów oceniania, klasyfikowania i promowania uczniów i słuchaczy oraz przeprowadzania egzaminów i sprawdzianów w szkołach publicznych (Dz. U. Nr 29, poz. 323) uczniowie niesłyszący i słabosłyszaccy mogą być natomiast zwolnieni z nauczania drugiego języka obcego.

Nauczanie języka obcego uczniów z uszkodzeniami słuchu jest więc fenomenem stosunkowo nowym. Wymienione powyżej rozporządzenia dały początek regularnej edukacji językowej uczniów niesłyszących i słabosłyszących, jednak do tej pory brak jest badań nad efektywnością nauczania językowego tej grupy uczniów.

Poniższy artykuł jest pierwszą z serii zaplanowanych publikacji, których celem jest uzupełnienie tej luki o wiarygodne dane informujące o efektach nauczania uczniów niesłyszących i słabosłyszących w zakresie języka obcego. Ze względu na fakt, iż głównym językiem nauczanym w szkołach specjalnych dla uczniów z uszkodzeniami słuchu jest język angielski, przeprowadzone analizy dotyczą tego języka. Celem artykułu jest zatem określenie, na podstawie analizy prac uczniów niesłyszących i słabosłyszących, jakie prezentują oni kompetencje w zakresie podstawowych umiejętności językowych, takich jak czytanie ze zrozumieniem, znajomość słownictwa, umiejętne stosowanie reguł gramatyki, sprawność komunikowania się w języku angielskim w codziennych sytuacjach oraz umiejętność przygotowania samodzielnej wypowiedzi pisemnej w języku angielskim. Przeprowadzona analiza dotyczy uczniów na wszystkich etapach nauczania i zakończona jest prezentacją opracowania dotyczącego oczekiwanego zakresu kompetencji uczniów niesłyszących i słabosłyszących w posługiwaniu się językiem angielskim.

\section{Specjalne potrzeby edukacyjne uczniów niesłyszących na lekcjach języka obcego}


Uszkodzenie słuchu, przy braku współwystępujących innych zaburzeń obniżających funkcjonowanie poznawcze, nie ogranicza zdolności dzieci i młodzieży niesłyszącej do uczenia się, jednocześnie jednak wada słuchu oznacza, że uczeń ma w znaczny sposób ograniczone zarówno możliwości percepcji, jak i ekspresji językowej, co wiąże się z odmiennym funkcjonowaniem narządów zmysłów, a także takich procesów, jak zapamiętywanie i myślenie formalne (Bebko 1984, Bebko i in. 1990, Heiling 1995, Bebko Marschark 1998, Marschark i in. 2002, Domagała-Zyśk 2001, 2006, Bavalier 2006, MacSweeney 1998, Parasnis 1998, Parasnis i in. 1996, Rettenbach 1999, Samar i in. 1998, Leybaert 1993, por. też Stachyra 2001). Uczeń niesłyszący nie nabywa języka poprzez podsłuchiwanie przypadkowych rozmów, słuchanie radia czy spontaniczne konwersacje, a wady wymowy związane z niedosłuchem utrudniaja opanowanie poprawnej wymowy słów w danym języku. Dla wielu osób z uszkodzeniami słuchu jest jednak możliwe opanowanie pisemnej formy języka (czytanie i pisanie), a także, w indywidualnie określonym stopniu, sprawności mówienia i słuchania. Zakres opanowania tych umiejętności zależy od stopnia uszkodzenia słuchu, efektywności zastosowanej rehabilitacji oraz metod i technik pracy nauczyciela języka obcego (por. Domagała-Zyśk 2001, 2008a, 2008b).

Dotychczasowe badania na gruncie surdoglottodydaktyki (DomagałaZyśk 2003), prowadzone jednak głównie w grupach dorosłych osób z uszkodzeniami słuchu, informują nas, iz $\mathrm{w}$ związku $\mathrm{z}$ ogromnym zróżnicowaniem przyczyn i objawów uszkodzenia słuchu, naczelną zasadą prowadzenia zajęć edukacyjnych $z$ tą grupą dzieci i młodzieży powinna być zasada indywidualizacji, respektowania jednostkowych predyspozycji i ograniczeń każdego z uczniów. Uczniowie niesłyszący różnią się bowiem między sobą pod względem prezentowanej motywacji do uczenia się (Domagała-Zysk 2010a), wybierają zróżnicowane style uczenia się (DomagałaZyśk 2010b), a w zależności od uwarunkowań biologicznych, psychologicznych, i edukacyjnych, sa $w$ stanie $w$ różnym zakresie opanować sprawność posługiwania się językiem ojczystym, co z kolei w znacznym stopniu warunkuje ich predyspozycje do nauki języka obcego.

Szczególnie trudne w sytuacji konieczności oceny osiagnięć ucznia z niepełnosprawnością słuchu w zakresie języków obcych staje się zadanie zmierzenia efektów nauczania i określenia kompetencji, które uczeń nabył/powinien nabyć na danym etapie nauczania. Jest to uwarunkowane przede wszystkim ogromnym zróżnicowaniem tej grupy uczniów, bowiem zaliczamy do niej osoby różniące się między sobą etiologią wady słuchu, czasem jej powstania i zdiagnozowania oraz głębokością i typem uszkodzenia (por. Krakowiak 2003). W kontekście nauczania języka bardzo istotnym czynnikiem różnicującym uczniów niesłyszących jest także rodzaj i zakres podejmowanej wobec nich terapii językowej, ponieważ zupełnie inaczej można planować pracę z uczniem mówiącym (rehabilitowanym metodami oralistycznymi), w inny zaś 
sposób należy pracować z uczniem posługującym się w komunikacji językiem migowym. Należy także pamiętać, że w kontekście oceny efektów nauczania ważne jest wzięcie pod uwagę nie tylko osiagnięć ucznia w zakresie podniesienia kompetencji językowej w nauczanym języku, lecz także poziomu osiąnnięcia innych celów, które stawiane są przed lektoratem języka obcego dla uczniów z uszkodzonym narządem słuchu (por. Domagała-Zyśk 2006). Ważne jest zatem ocenienie, w jakim zakresie lektorat języka obcego spełnił swoją rolę jako sytuacja dydaktyczna kompensująca doświadczaną przez ucznia deprywację poznawcza, społeczną i zajęciowa, a zatem ocena, na ile uczenie się języka obcego pełni w życiu ucznia niesłyszącego funkcję nie tylko wiedzotwórczą, ale także psychoterapeutyczną.

Wyznaczenie i ocena kompetencji językowych uczniów z uszkodzeniami słuchu są także trudne ze względu na barierę komunikacyjną i trudności większzości uczniów niesłyszących w zakresie produkcji mowy obcojęzycznej. Nauczyciele w każdej ze szkół specjalnych dla niesłyszących i słabosłyszących pracuja w oparciu o samodzielnie wypracowane metody i techniki pracy, indywidualnie podejmuja także decyzje odnośnie oceniania poziomu kompetencji uczniów. Ewaluacja pracy ucznia przybiera najczęściej formę pisemną i dotyczy oceny sprawności rozumienia czytanego tekstu o odpowiednio dobranym poziomie trudności, ocenę zakresu znajomości słownictwa, ocenę sprawności w zakresie poprawnego stosowania w praktyce reguł gramatycznych oraz kompetencje w zakresie tworzenia tekstu pisanego.

Obiektywna ocena poziomu znajomości języków obcych wśród uczniów niesłyszących dokonywana była do tej pory jedynie w odniesieniu do uczniów klas licealnych zdających maturę (od roku 2005), a od 2009 roku, w związku z pojawieniem się części językowej w arkuszach egzaminu gimnazjalnego, staje się to możliwe także w odniesieniu do uczniów gimnazjum. Brak jest jednak badań czy opracowań metodycznych, które prezentowałyby i analizowałyby osiagnięte przez uczniów niesłyszących kompetencje w innych niż egzamin kontekstach.

\section{Badania własne nad poziomem znajomości języka angielskiego jako obcego wśród uczniów różnych typów szkół}

Aby określić poziom kompetencji językowej niesłyszących i słabosłyszących uczniów różnych typów szkół specjalnych, zaprojektowano i przeprowadzono badania empiryczne.

\section{Cel badań}

Za cel badań własnych postawiono zadanie zbadania, jaki jest poziom znajomości języka angielskiego wśród niesłyszących uczniów szkół specjalnych na poziomie szkoły podstawowej, gimnazjum i szkoły ponadgimnazjalnej. Ze względu na potrzebę zachowania jak największej homogeniczności badanej grupy, w badaniach nie uczestniczyły osoby niesłyszące uczące się w integracji 
lub w szkołach ogólnodostępnych. Należy podkreślić, że celem badania nie było określenie średniego poziomu znajomości języka w grupie uczniów niesłyszących, ale określenie maksymalnego poziomu osiaganych przez tę grupę uczniów kompetencji językowych w zakresie posługiwania się językiem angielskim, dlatego analizie poddano prace przygotowane przez uczniów osiągających najlepsze wyniki w danych typach szkół.

badawcze:

Przed przystąpieniem do badań sformułowano następujące problemy

1. Jaki jest poziom kompetencji leksykalnej badanych uczniów w zakresie posługiwania się językiem angielskim?

2. Jaki jest poziom kompetencji badanych uczniów w zakresie prawidłowego stosowania struktur gramatycznych w języku angielskim?

3. Jaki jest poziom sprawności badanych uczniów w zakresie stosowania wyrażeń potrzebnych w komunikacji w codziennych sytuacjach z wykorzystaniem języka angielskiego?

4. Jaki jest poziom sprawności badanych uczniów w zakresie rozumienia czytanego tekstu napisanego w języku angielskim?

\section{Organizacja badań}

W celu określenia poziomu znajomości języka angielskiego wśród uczniów niesłyszących i słabosłyszących różnych typów szkół przeanalizowano arkusze konkursowe z VII Ogólnopolskiego Konkursu Znajomości Jezyka Angielskiego dla Ucznióm Niestyszacych. Jest to przedsięwzięcie, które organizowane jest każdego roku przez inny ośrodek kształcący dzieci i młodzież niesłysząca. W dniach 23-25 kwietnia 2010 siódmy już konkurs odbył się w Ośrodku SzkolnoWychowawczym dla Dzieci i Młodzieży Niesłyszącej w Otwocku Śródborowie. Konkurs odbywał się w trzech kategoriach: Kategoria I obejmowała uczniów szkół podstawowych z klas piątych i szóstych i uczestniczyło w niej 12 uczniów ze szkół specjalnych dla uczniów niesłyszących z terenu całej Polski. Kategoria II przeznaczona była dla uczniów wszystkich klas gimnazjów i wzięło w niej udział 39 uczniów, zaś w kategorii III, obejmującej uczniów szkół ponadgimnazjalnych, startowało 18 uczniów z klas I i II. Uczestnicy konkursu zostali wytypowani do uczestnictwa w nim przez swoich nauczycieli i byli to uczniowie osiagający najwyższe wyniki w nauce w zakresie języka angielskiego.

Analizowane zadania konkursowe zostały przygotowane przez nauczycieli z różnych szkół specjalnych dla dzieci niesłyszących z terenu całej Polski, a następnie nauczyciele - angliści z Ośrodka w Otwocku przygotowali wersję ostateczną arkusza. Dla potrzeb badań zebrano i poddano analizie arkusze wszystkich uczestników, łącznie było to 69 prac konkursowych (por. Tabela 1).

\begin{tabular}{|l|c|c|}
\hline & $\begin{array}{c}\text { Liczba uczniów } \\
(\mathrm{N})\end{array}$ & $\begin{array}{c}\text { Procent } \\
(\%)\end{array}$ \\
\hline I - szkoły podstawowe & 12 & $17 \%$ \\
\hline
\end{tabular}


Ewa Domagała-Zyśk

\begin{tabular}{|l|c|c|}
\hline II - gimnazja & 39 & $57 \%$ \\
\hline III - szkoły ponadgimnazjalne & 18 & $26 \%$ \\
\hline RAZEM & 69 & $100 \%$ \\
\hline
\end{tabular}

Tabela 1: Uczestnicy badań z podziałem na typy szkół. 
Poziom znajomości języka angielskiego jako obcego wśród niesłyszących uczniów szkół podstawowych - badania własne

W arkuszu konkursowym dla niesłyszących uczniów szkół podstawowych zamieszczono 10 zadań, za rozwiązanie których uczeń mógł zdobyć maksymalnie 70 punktów. Zadania sprawdzały kompetencje językowe w następujących kategoriach: I. Rozumienie czytanego tekstu (zad. 3); II. Znajomość słownictwa (zad. 1, 2, 5, 7, 8, 9, 10); III. Gramatyka (zad. 6); IV. Komunikacja w sytuacjach życia codziennego (zad. 4). Analiza struktury arkusza prowadzi do konkluzji, iż na tym poziomie edukacji uczniowie pracuja na lekcjach języka obcego głównie na poziomie wyrazu - poznają angielskie słowa i przyporządkowują im znaczenie w języku polskim ${ }^{1}$. Zadania sprawdzające te umiejętności stanowiły 69\% całości testu, a ich prawidłowe rozwiązanie pozwalało na otrzymanie aż 48 z 70 punktów. Wśród zadań leksykalnych największa liczba poleceń dotyczyła znajomości rzeczowników: w zadaniach sprawdzających znajomość słownictwa pojawiło sie ich aż 78 (74,2\%). Mniejszą uwagę autorzy arkusza przywiązali do znajomości liczebników kardynalnych, których pojawiło się w tekście 11 (10,5\%); znacznie mniej było też czasowników (8, co stanowi 7,7\%), przymiotników i przyimków (po 4, co stanowi 3,8\% dla każdej z kategorii). Pozostałym kategoriom przyporządkowano tylko po jednym zadaniu, które stawiły odpowiednio: rozumienie czytanego tekstu - 10 z 70 punktów (14\%), gramatyka 6 punktów $(8,5 \%)$, komunikacja w sytuacjach życia codziennego 6 punktów (8,5\%). Dane te zebrano w Tabeli 2 i 3.

\begin{tabular}{|l|c|c|}
\hline Kategoria & $\begin{array}{c}\text { Udział w całości } \\
\text { testu } \\
(\mathrm{N})\end{array}$ & $\begin{array}{c}\text { Procentowy udział } \\
\text { w całości testu } \\
(\%)\end{array}$ \\
\hline Rozumienie czytanego tekstu & 10 & $14 \%$ \\
\hline Słownictwo - całość & 48 & $69 \%$ \\
\hline Gramatyka & 6 & $8,5 \%$ \\
\hline Komunikacja & 6 & $8,5 \%$ \\
\hline RAZEM & 70 & $100 \%$ \\
\hline
\end{tabular}

Tabela 2: Udział poszczególnych kategorii zadań w arkuszu - szkoły podstawowe.

\footnotetext{
1 Warto zaznaczyć, iż w badaniach Kurkowskiego (1996) określono, że w zasobie leksykalnym języka ojczystego w przypadku niesłyszących dzieci sześcioletnich rzeczowniki stanowią średnio 75\% wśród wszystkich części mowy, a u dzieci o opóźnionym rozwoju leksykalnym rzeczowniki moga stanowić nawet $100 \%$ słownika. Czasowniki stanowią średnio $10 \%$, podobnie jak przymiotniki - 11\%; znacznie rzadziej dzieci niesłyszące używają liczebników (3\%) i przyimków(1\%).
} 
Ewa Domagała-Zyśk

\begin{tabular}{|l|c|c|}
\hline Kategoria & $\begin{array}{c}\text { Liczbowy udział } \\
\text { w kategorii słownictwo } \\
(\mathrm{N})\end{array}$ & $\begin{array}{c}\text { Procentowy udział } \\
\text { w kategorii słownictwo } \\
(\%)\end{array}$ \\
\hline Słownictwo - rzeczowniki & 78 & $74,2 \%$ \\
\hline Słownictwo - liczebniki & 11 & $10,5 \%$ \\
\hline Słownictwo - czasowniki & 8 & $7,7 \%$ \\
\hline Słownictwo - przymiotniki & 4 & $3,8 \%$ \\
\hline Słownictwo - przyimki & 4 & $3,8 \%$ \\
\hline RAZEM & 105 & $100 \%$ \\
\hline
\end{tabular}

Tabela 3: Udział poszczególnych części mowy w zadaniach arkusza - szkoły podstawowe.

Niesłyszący uczestnicy konkursu w kategorii szkół podstawowych mieli spore trudności w rozwiązaniu zadań konkursowych: średni wynik osiagnięty przez grupe wynosił 40,25 punktów, czyli 57,55\%. Największe trudności zaobserwowano w zadaniu sprawdzającym znajomość gramatyki (było to zadania polegające na dopasowaniu do zdań operatorów czasu teraźniejszego w odpowiedniej formie), ponieważ uczniowie w tej kategorii rozwiąali poprawnie średnio połowę zadania (51\%). Trudne okazały się także zadania sprawdzające znajomość leksyki, z których rozwiązano także niewiele ponad połowę $(52 \%)$. Znacznie lepsze wyniki uczniowie niesłyszący osiagnęli w kategorii rozumienia czytanego tekstu (średnio 77\% poprawnych odpowiedzi); dobry był także wynik osiąnięty w ćwiczeniu badającym sprawności komunikacyjne (76\%). Wyniki zebrano w Tabeli 4.

\begin{tabular}{|l|c|c|c|}
\hline Kategoria & $\begin{array}{c}\text { Maksymalna } \\
\text { liczba punktów }\end{array}$ & $\begin{array}{l}\text { Średni } \\
\text { wynik }\end{array}$ & $\begin{array}{c}\% \text { odpowiedzi } \\
\text { poprawnych }\end{array}$ \\
\hline $\begin{array}{l}\text { Rozumienie } \\
\text { czytanego tekstu }\end{array}$ & 10 & 7,77 & $77 \%$ \\
\hline Słownictwo-całość & 48 & 24,83 & $52 \%$ \\
\hline Gramatyka & 6 & 3,08 & $51 \%$ \\
\hline Komunikacja & 6 & 4,58 & $76 \%$ \\
\hline RAZEM & 70 & 40,25 & $57,55 \%$ \\
\hline
\end{tabular}

Tabela 4: Wyniki osiagnięte przez grupę uczestników w poszczególnych kategoriach szkoły podstawowe.

\section{Poziom znajomości języka angielskiego jako obcego wśród niesłyszących uczniów gimnazjów - badania własne}

Arkusze konkursowe dla niesłyszącej młodzieży gimnazjalnej zawierały 10 zadań, które przyporządkowano do 5 kategorii: I. Rozumienie czytanego tekstu (zad. 1 i 9); II. Słownictwo (zad. 2,7 i 8); III. Gramatyka (zad. 3 i 6); IV. Komunikacja językowa w sytuacjach codziennych (zad. 4 i 5 ) oraz V. Wypowiedź pisemna (opis obrazka w formie odpowiedzi na zamieszczone pytania, zad. 10). Dane przedstawiono w Tabeli 5. 


\begin{tabular}{|l|c|c|}
\hline Kategoria & $\begin{array}{c}\text { Udział } \\
\text { w całości testu } \\
(\mathrm{N})\end{array}$ & $\begin{array}{c}\text { Procentowy } \\
\text { udział w całości testu } \\
(\%)\end{array}$ \\
\hline Rozumienie czytanego tekstu & 12 & $17 \%$ \\
\hline Słownictwo & 22 & $31 \%$ \\
\hline Gramatyka & 13 & $19,5 \%$ \\
\hline Komunikacja & 15 & $21 \%$ \\
\hline Wypowiedź pisemna & 8 & $11,5 \%$ \\
\hline RAZEM & 70 & $100 \%$ \\
\hline
\end{tabular}

Tabela 5: Udział poszczególnych kategorii zadań w arkuszu - gimnazja.

Analiza struktury arkusza pozwala na zauważenie istotnych różnic w stosunku do arkusza dla szkół podstawowych. Znajomość słownictwa w języku obcym jest nadal kategorią dominującą w teście, jednak nie jest to dominacja tak silna, jak w przypadku szkół podstawowych, gdzie zadania te stanowiły 69\% wszystkich zadań; w wersji dla gimnazjalistów zadania sprawdzające znajomość słownictwa stanowiły 31\% wszystkich zadań. Do 19,5\% wzrosła liczba zadań sprawdzających znajomość gramatyki, zadania sprawdzające kompetencje komunikacyjne w codziennych sytuacjach stanowiły $21 \%$ zadań, zaś umiejętność rozumienia czytanego tekstu sprawdzano w zadaniach stanowiących 17\% wszystkich zadań testowych. Gimnazjaliści mieli za zadanie wykonać także ćwiczenie o charakterze otwartym, poproszono ich o opisanie ilustracji w formie odpowiedzi na przygotowane pytania. Ostatnie z pytań odnosiło się do osobistych doświadczeń uczestników i było pytaniem o ulubiony sport. Za przygotowanie wypowiedzi pisemnej można było otrzymać 11,5\% punktów z całego testu. Zadania gramatyczne sprawdzały umiejętność rozróżniania czasów Present Simple, Past Simple i Present Continuous, sprawność stopniowania przymiotników regularnych i nieregularnych oraz znajomość zasad używania kwantyfikatorów some i any. Ćwiczenia sprawdzające znajomość słownictwa wymagały od uczniów znajomości przede wszystkim rzeczowników, następnie liczebników, czasowników i przymiotników.

Analiza osiągniętych przez poszczególnych uczniów niesłyszących rezultatów ukazała, iź średni wynik osiagnięty przez uczniów wynosił niewiele ponad połowę możliwych do osiągnięcia punktów (56,8\%). Szczególną trudność sprawiły większości osób zadania sprawdzające znajomość gramatyki poprawnie rozwiązano tylko $29 \%$ z przygotowanych zadań, równie trudne okazało się przygotowanie wypowiedzi pisemnej, za która uczniowie otrzymali średnio tylko trzecią część możliwych do osiąnięcia punktów (30\%). Najlepsze wyniki osiagnięto w zakresie sprawności rozumienia czytanego tekstu $(80 \%$ poprawnych odpowiedzi) oraz znajomości słownictwa $(77 \%$ poprawnych odpowiedzi), niewiele gorzej uczniowie poradzili sobie $z$ zadaniem 
sprawdzającym umiejętność komunikowania się w codziennych sytuacjach $(68 \%$ poprawnych odpowiedzi). Wyniki liczbowe i procentowe zebrano w Tabeli 6.

\begin{tabular}{|l|c|c|c|}
\hline Kategoria & $\begin{array}{c}\text { Maksymalna liczba } \\
\text { punktów }\end{array}$ & $\begin{array}{c}\text { Średnia poprawnych } \\
\text { odpowiedzi }\end{array}$ & $\begin{array}{c}\text { Procent odpowiedzi } \\
\text { poprawnych }\end{array}$ \\
\hline $\begin{array}{l}\text { Rozumienie } \\
\text { czytanego tekstu }\end{array}$ & 52 & 41,60 & $80 \%$ \\
\hline Słownictwo & 22 & 16,95 & $77 \%$ \\
\hline Gramatyka & 13 & 3,72 & $29 \%$ \\
\hline Komunikacja & 15 & 10,13 & $30 \%$ \\
\hline $\begin{array}{l}\text { Wypowiedź } \\
\text { pisemna }\end{array}$ & 8 & 2,44 & $56,8 \%$ \\
\hline RAZEM & 70 & 42,85 & \\
\hline
\end{tabular}

Tabela 6: Wyniki osiagnięte przez grupę niesłyszących gimnazjalistów w poszczególnych kategoriach.

Największą trudność sprawiło uczniom niesłyszącym zadanie polegające na zapisaniu prawidłowej formy przymiotników w różnych stopniach, które rozwiązano prawidłowo tylko w 18\%. Szczegółowa analiza popełnionych w tym zakresie błędów ujawniła, że często nie były to błędy typowo popełniane w takich zadaniach, tzn. polegające na nieprawidłowym zastosowaniu końcówek -er i -est w sytuacjach, kiedy należy użyć przed przymiotnikiem wyrazów more i most. Niesłyszący gimnazjaliści próbowali poradzić sobie z tym zadaniem stosując tak niecodzienne formy jak: the interested, more goodest, more intersestingest, goodthe, oldthe, olds, gooding, interestingszy, najgoodszy, inbeatifulled, betters, the bestiest, the bestly, the very oldes, które z jednej strony ukazuja całkowita nieznajomość zasad tworzenia stopnia wyższego i najwyższego przymiotników, z drugiej jednak strony pokazują zdolność osób niesłyszących do twórczości językowej, chęć eksperymentowania z językiem, nie poddawanie się w sytuacji trudności językowych (por. Krakowiak 2003).

Analizie jakościowej poddano także odpowiedzi uczniów na pytania otwarte w zadaniu polegającym na stworzeniu opisu obrazka. Uczniom postawiono następujace pytania: How many people are there on the picture?, What are they doing?, What's the weather like? What's your favorite sport? 'Tylko 30\% wypowiedzi uczniów było prawidłowych. Wypowiedzi skonstruowane nieprawidłowo pokazuja pewne tendencje obecne w swobodnych wypowiedziach osób niesłyszących, do których należą:

- Budowanie zdań składających się ze stojących obok siebie wyrazów, które nie pozostają ze sobą w żadnych związkach składniowych, a ich kolejność jest przypadkowa, np. I wath picture to family and sky; The picture are many people; Sport favorite football, swimming sport; I am favourite sport basketball ride a bike; Favourite sport yours: ski, football, bockey. 
- Swobodne używanie czasowników, bez przykładania uwagi do ich liczby i formy, np. On the picture is four people, I is favourite sport foolball and basketball.

- Zaburzony szyk zdania, np. There are on the picture four peopl; Picture the on there are people many; They doing are skiing.

- Nieprawidłowe stosowanie form czasownika wynikających z użycia określonego czasu, np. I'm see picture 4 peoples; They are ski

- Nieprawidłowa budowa wyrazów w liczbie mnogiej, np. On the picture there are four peoples

- Wtrącanie słów w języku polskim do wypowiedzi w języku angielskim, np. Doing they are have na narty

- Używanie kalek językowych, np. My favourite sport is free running.

\section{Poziom znajomości języka angielskiego jako obcego wśród niesłyszących uczniów szkół ponadgimnazjalnych - badania własne}

Arkusze konkursowe dla uczniów szkół ponadgimnazjalnych zawierały 9 zadań, podzielonych na 5 kategorii, identycznych jak w przypadku testu dla młodzieży gimnazjalnej, były to zatem: I. Rozumienie czytanego tekstu (zad. 1 i 8), II. Słownictwo (zad. 2, 3 i 7); III. Gramatyka (zad. 4 i 5); IV. Komunikacja językowa w codziennych sytuacjach (zad. 6) oraz V. Wypowiedź pisemna (zad. 9). Dane informujące o procentowym udziale poszczególnych kategorii w całości testu zamieszczono w Tabeli 7.

\begin{tabular}{|l|c|c|}
\hline Kategoria & $\begin{array}{c}\text { Udział } \\
\text { w całości testu } \\
(\mathrm{N})\end{array}$ & $\begin{array}{c}\text { Procentowy } \\
\text { udział w całości testu } \\
(\%)\end{array}$ \\
\hline Rozumienie czytanego tekstu & 22 & $31 \%$ \\
\hline Słownictwo & 23 & $33 \%$ \\
\hline Gramatyka & 10 & $14 \%$ \\
\hline Komunikacja & 5 & $7 \%$ \\
\hline Wypowiedź pisemna & 10 & $14 \%$ \\
\hline RAZEM & 70 & $100 \%$ \\
\hline
\end{tabular}

Tabela 7: Udział poszczególnych kategorii zadań w arkuszu - szkoły ponadgimnazjalne.

Analiza formalnej strony testu pozwala stwierdzić, że wśród zadań dla niesłyszących uczniów szkół ponadgimnazjalnych większą niż na poprzednich etapach edukacji uwagę przykłada się do sprawności rozumienia czytanego tekstu, zadania te stanowią 31\% zadań całego testu. Ważną częścią arkusza pozostaja zadania sprawdzające znajomość słownictwa, stanowiąc trzecią część wszystkich zadań (33\%), istotną częścią testu pozostaje także część gramatyczna, stanowiąc 14\% wszystkich zadań i część sprawdzająca umiejętność tworzenia własnej wypowiedzi, która stanowi kolejne 14\% zadań. Najmniej istotną częścią testu jest kategoria IV, sprawdzająca umiejętność komunikacji językowej w codziennych 
sytuacjach, która stanowi tylko 7\% całości testu, co jest wartością trzykrotnie mniejszą niż liczba punktów przyznawana za tę kategorię uczniom gimnazjum (por. Tabela 5). Opierając się na analizowanych materiałach należy zatem zauważyć, że na etapie szkoły ponadgimnazjalnej w nauczaniu niesłyszących sprawność komunikowania się staje się coraz mniej ważna, ustępując miejsca sprawnościom związanym z bierną recepcją języka (czytanie) oraz produkcją języka w formie pisemnej, zwłaszcza w formie zamkniętych zadań gramatycznych i leksykalnych.

Średni wynik osiagnięty przez badanych uczniów wynosi $61,2 \%$; jest więc nieco wyższy od wyniku osiagniętego przez gimnazjalistów, jednocześnie jednak oznacza, że dla uczestników konkursu test okazał się zbyt trudny. Wyższe od średniej wyniki uczestnicy osiagnęli w kategorii I, sprawdzającej rozumienie czytanego tekstu, kategorii IV, sprawdzającej umiejętności komunikacyjne, oraz w kategorii II sprawdzającej znajomość słownictwa (odpowiednio 76\%, 73\% oraz $71 \%$ poprawnych odpowiedzi). Najtrudniejszym zadaniem okazało się przygotowanie wypowiedzi pisemnej, która miała formę opisu ilustracji wykonywanego poprzez udzielenie odpowiedzi na przygotowane przez autorów testu pytania ('́redni wynik za to zadanie wynosił 31\%), trudne okazały się także zadania gramatyczne, sprawdzające znajomość form czasowników nieregularnych w czasie Past Simple oraz umiejętność zastosowania operatorów w czasach Present Simple, Past Simple oraz Future Simple (55\% odpowiedzi poprawnych). Wyniki zestawiono w Tabeli 8.

\begin{tabular}{|l|c|c|c|}
\hline Kategoria & $\begin{array}{c}\text { Maksymalna } \\
\text { liczba } \\
\text { punktów }\end{array}$ & $\begin{array}{c}\text { Średnia } \\
\text { odpowiedzi } \\
\text { poprawnych }\end{array}$ & $\begin{array}{c}\text { Procent } \\
\text { odpowiedzi } \\
\text { poprawnych }\end{array}$ \\
\hline Rozumienie czytanego tekstu & 22 & 16,6 & $76 \%$ \\
\hline Słownictwo & 23 & 16,2 & $71 \%$ \\
\hline Gramatyka & 10 & 5,5 & $55 \%$ \\
\hline Komunikacja & 5 & 3,7 & $73 \%$ \\
\hline Wypowiedź pisemna & 10 & 3,1 & $31 \%$ \\
\hline RAZEM & 70 & 45,1 & $61,2 \%$ \\
\hline
\end{tabular}

Tabela 8: Wyniki osiąnięte przez grupę niesłyszących uczniów szkół ponadgimnazjalnych w poszczególnych kategoriach.

Szczegółowo przeprowadzono analizę samodzielnych wypowiedzi uczniów (zad. 9, kategoria V). Badanym przedstawiono ilustrację i zadano pięć następujacych pytań: Who can you see in the photograph?, Where are they?, What are they doing now?, What are they wearing?, What is your favorite subject? Niskie wyniki osiągane przez uczniów w odpowiedzi na to pytanie wynikały przede wszystkim z zaburzonego szyku zdania, wynikającego z pominięcia niektórych elementów zdania, zwłaszcza operatorów, przedimków i przyimków, lub ich błędnego użycia, np. They are a classroom; They are reading a books; They are favorite subject with geography. Częstym błędem było także nieprawidłowe użycie form 
czasownikowych (They are learn; They are do write homework, She are wearing t-shirt; Now they are study) oraz błędnych form rzeczownika, co wynikało z nieznajomości zasad gramatycznych i wyjątków od nich lub błędów w zakresie poprawnej pisowni wyrazów, np. childs, childrens, scholl (=school). Pomimo tych trudności połowa badanych zadeklarowała, iż język angielski jest ich ulubionym przedmiotem w szkole.

Podsumowując analizę wyników osiagniętych przez badanych uczniów można stwierdzić, że nauczanie języka angielskiego uczniów niesłyszących i słabosłyszących przynosi zadowalające efekty. Uczniowie wszystkich typów szkół wykazali się kompetencjami przede wszystkim w zakresie odbioru języka i we wszystkich trzech typach szkół zaprezentowali sprawność czytania na poziomie przekraczającym 75\% (średni wynik dla wszystkich typów szkół wynosi 77,7\%). Zaskakującym jest fakt, że równie wysoki wynik $(72,3 \%)$ uczniowie osiagnęli w kategorii Komunikacja $w$ sytuacjach życia codziennego, co świadczy, że znają oni podstawowe wyrażenia pozwalające na sprawne komunikowanie się mową lub prowadzenie rozmowy poprzez zapisywanie niektórych wyrażeń. Wynik ten przeczy też tezie o tym, jakoby uczniom niesłyszącym nie zależało na nabywaniu sprawności posługiwania się językiem potrzebnym do codziennej komunikacji, a potwierdza słuszność wysiłków tych nauczycieli, którzy stosują w nauczaniu niesłyszących podejście komunikacyjne i uczą języka obcego po to, aby także i uczeń z uszkodzeniami słuchu mógł posługiwać się nim w komunikacji. Uczniowie gimnazjum i liceum wykazali się też stosunkowo dobrą znajomością słownictwa, osiagając wyniki powyżej 70\%. Wynik dla całej badanej grupy wynosi 66,7\% i jest zaniżony przez niski wynik osiagnięty przez uczniów szkół podstawowych (52\%). Duże trudności natomiast zaobserwowano w zakresie gramatyki (średni wynik dla całej grupy wynosi 45\%), co niewątpliwie wskazuje na konieczność podjęcia dalszej intensywnej pracy nad nabyciem kompetencji w zakresie poprawnego gramatycznie posługiwania się językiem. Uczniowie gimnazjów i liceów osiagnęli także bardzo niskie wyniki w zakresie tworzenia samodzielnych wypowiedzi (zdań) w języku obcym, zdobywając jedynie 30,5\% możliwych do zdobycia punktów.

\section{Prezentacja opracowania pt. „Zakres oczekiwanych kompetencji uczniów z uszkodzeniami słuchu w posługiwaniu się językiem angielskim - propozycje kryteriów"}

Zaprezentowane powyżej analizy dokumentują osiagnięcia, ale i trudności badanych uczniów, zwłaszcza w zadaniach z zakresu pisemnej ekspresji językowej. Jednocześnie są potwierdzeniem tezy, iż w przypadku uczniów niesłyszących i słabosłyszących możliwe jest nabycie podstawowych kompetencji umożliwiających odbiór treści w języku obcym oraz budowanie w nim zrozumiałych komunikatów. Wyniki te mobilizują także do podjęcia intensywnych wysiłków w celu udzielenia bardziej kompetentnego wsparcia tej grupie uczniów i ich nauczycielom. 
Podstawową trudnością w nauczaniu uczniów niesłyszących i słabosłyszących, poza brakiem specjalistycznych podręczników metodycznych i ciekawych pomocy dydaktycznych, jest brak opracowanych dla tej grupy uczniów celów edukacji językowej, kryteriów oceniania czy też zakresu oczekiwanych od uczniów kompetencji. (por. Domagała-Zysk 2011 (w druku). Nauczyciele radzą sobie $\mathrm{z}$ tą trudnością opracowując kryteria na użytek klas/uczniów, z którymi pracuja; konieczne wydaje się jednak przygotowanie kryteriów zewnętrznych (obiektywnych), ułatwiających pracę nauczycieli, a jednocześnie będących punktem odniesienia dla całej grupy uczniów niesłyszących i słabosłyszących.

Proces tworzenia dokumentu pt. „Zakres kompetencji uczniów niesłyszących i słabosłyszących w posługiwaniu się językiem angielskim" przebiegał w kilku etapach. W pierwszym etapie (kwiecień-czerwiec 2010) wśród nauczycieli pracujących w szkołach specjalnych dla uczniów niesłyszących i słabosłyszących przeprowadzono badania ankietowe, w których poproszono o ocenę kompetencji nauczanych przez nich uczniów w czterech zakresach: czytania, pisania, słuchania i mówienia w języku angielskim. Ankietę uzupełniło i odesłało 18 nauczycieli z 15 szkół specjalnych dla dzieci i młodzieży niesłyszącej². Następnie, na podstawie dotychczasowej wiedzy z zakresu surdoglottodydaktyki (Domagała-Zyśk 2003, 2006, 2009a, 2009b, 2010) oraz nadesłanych przez nauczycieli informacji, w oparciu o Europejskie Portfolio Jesylkowe (2005) przygotowano wstępną wersję dokumentu, którą z kolei rozesłano nauczycielom do konsultacji. Po naniesieniu nadesłanych przez nich poprawek powstała ostateczna wersja opracowania.

\subsection{Słuchanie/rozumienie informacji przekazanych przez interlokutora na piśmie}

Słuchanie jest pierwszą ze sprawności podlegająca ocenie w Europejskim Portfolio Jesylkonym (2005) i pomimo trudności doświadczanych przez uczniów niesłyszacych i słabosłyszących szczególnie w tym obszarze, nie powinno stać się kategoria umiejętności nie ćwiczonych w tej grupie uczniów. Praktyka uczy bowiem, że większość uczniów z uszkodzeniami słuchu korzysta z narządu słuchu w porozumiewaniu się w języku narodowym i odczytuje z ust rozmówców pewną część przekazywanych przez nich informacji, skutecznie pomagając sobie w tej czynności stosowaniem pisma, np. przy użyciu papieru lub monitorów np. telefonów komórkowych. Odczytywanie $z$ ust mowy obcojęzycznej jest umiejętnością trudniejszą niż odczytywanie $z$ ust języka narodowego, jednak większość osób niesłyszących może podejmować próby opanowania podstaw tej umiejętności.

${ }^{2}$ W Polsce działa 37 szkół specjalnych kształcących dzieci i młodzież niesłysząca (za: Katalog szkót 2010/2011, wyd. Zarząd Główny PZG). 
Oczekiwane kompetencje uczniów niesłyszących i słabosłyszących w zakresie słuchania/rozumienia interlokutora w czasie interakcji zawarto w Tabeli 1. Zawarte w Portfolio priorytety dostosowano do możliwości uczniów z uszkodzeniami słuchu, pomijając te, które wymagały złożonych reakcji językowych i sprawności rozumienia dłuższych i bardziej skomplikowanych wypowiedzi. Usunięto także te zadania, które wymagały słuchania w warunkach utrudniających/uniemożliwiających odczytywanie $z$ ust, np. słuchanie wiadomości radiowych, śledzenie filmu bez podpisów lub uczestnictwo w rozmowie prowadzonej przez kilka osób. Sprawności oczekiwane od uczniów szkół podstawowych i gimnazjów mieszczą się na poziomie językowym A1; od uczniów liceum wymagane są umiejętności częściowo wchodzące w zakres poziomu A1, zaś częściowo przypisane poziomowi A2.

\begin{tabular}{|l|l|}
\hline Typ szkoły & Kompetencje w zakresie słuchania/rozumienia interlokutora \\
\hline Szkoła podstawowa & $\begin{array}{l}\text { W miarę indywidualnych możliwości percepcyjnych: } \\
- \text { uczén odczytuje z ust/rozumie pojedyncze słowa i krótkie } \\
\text { wyrażenia (np. powitalne i pożegnalne) używane w codziennych } \\
\text { sytuacjach lub/i potrafi je zrozumieć, kiedy zostana zapisane }\end{array}$ \\
\hline gimnazjum & $\begin{array}{l}\text { W miarę indywidualnych możliwości percepcyjnych: } \\
\text { - uczeń odczytuje z ust rozmówcy/z kartki proste słowa i wyrażenia, } \\
\text { np. liczby, ceny i godziny, } \\
\text { - uczeń potrafi zrozumieć proste wskazówki powiedziane lub/i } \\
\text { zapisane w języku angielskim (np. jak dojść do określonego miejsca) }\end{array}$ \\
\hline liceum & $\begin{array}{l}\text { W miarę indywidualnych możliwości percepcyjnych: } \\
- \text { uczeń rozumie, kiedy ktoś mówi do niego powoli i wyraźnie o } \\
\text { prostych codziennych sytuacjach } \\
- \text { uczeń rozumie proste informacje zapisane przez interlokutora w } \\
\text { trakcie rozmów o codziennych sprawach } \\
- \text { uczeń potrafi zrozumieć temat prowadzonej rozmowy, jeśli } \\
\text { rozmówcy mówia powoli, zwracając się w jego stronę lub/i zapisuja } \\
\text { najważniejsze słowa/wyrażenia rozmowy na kartce } \\
- \text { uczeń potrafi zrozumieć podstawowe informacje śledząc napisy, } \\
\text { np. w wiadomościach TV lub na portalach internetowych }\end{array}$ \\
\hline
\end{tabular}

Tabela 1: Zakres kompetencji w obszarze słuchania/rozumienia informacji przekazanych przez interlokutora na piśmie.

\subsection{Czytanie}

Czytanie wyrazów, zdań i tekstów w języku obcym jest podstawową sprawnością, która powinna zostać osiagnięta przez uczniów niesłyszących i słabosłyszących w stopniu umożliwiającym im czynne posługiwanie się językiem obcym. Pracując nad tą sprawnością i oceniając postępy uczniów $z$ uszkodzeniami słuchu należy jednak pamiętać, że głuchota wiąże się z zaburzeniem nie tylko mowy, ale jezylka: sprawia, że osoby niesłyszące maja 
utrudniony dostęp do informacji językowych, trudniej jest im poznawać nowe słowa i używać ich nie tylko w mowie, ale także rozumieć ich znaczenie w tekstach i używać ich w wypowiedziach pisemnych (por. Domagała-Zyśk 2010a, 2010b). Z tego też powodu nie można zakładać, że uczeń z uszkodzeniami słuchu może bez przeszkód korzystać z tekstów pisanych. Potrzebne mu wsparcie obejmuje m.in. wyjaśnianie słów nieznanych w języku ojczystym oraz większą liczbę ćwiczeń utrwalających.

Oczekiwane kompetencje uczniów niesłyszących i słabosłyszących w zakresie czytania w języku angielskim zawarto w Tabeli 2. Kompetencje oczekiwane od uczniów szkoły podstawowej i gimnazjum nalezą do poziomu A1, licealiści powinni opanować w zakresie czytania kompetencje przynależne do poziomu A2.

\begin{tabular}{|c|c|}
\hline Typ szkoły & Kompetencje szczegółowe w zakresie czytania \\
\hline $\begin{array}{l}\text { szkoła } \\
\text { podstawowa }\end{array}$ & $\begin{array}{l}\text { - uczeń rozumie poznane wcześniej słowa i podstawowe wyrażenia } \\
\text { - uczeń rozumie proste polecenia, napisy i zdania napisane w jezzyku } \\
\text { obcym (np. parking, zakazpalenia, zakaz fotografowania itp.) } \\
\text { - uczeń rozumie proste komendy w programach komputerowych (np. } \\
\text { zapisź, myślij, kopiuy) } \\
\text { - uczeń potrafi odnaleźć w prostym tekście w języku obcym podstawowe } \\
\text { informacje, zwłaszcza te dotyczące ludzi }\end{array}$ \\
\hline gimnazjum & $\begin{array}{l}\text { - uczeń potrafi odnaleźć w tekście potrzebne informacje dotyczace ludzi } \\
\text { (wiek, miejsce zamieszkania, hobby itp.) oraz wydarzeń (kiedy i gdzie } \\
\text { odbywa się dane wydarzenie, np. film) } \\
\text { - uczeń potrafi zrozumieć prosty formularz (np. hotelowy) i wpisać swoje } \\
\text { dane osobowe } \\
\text { - uczeń potrafi zrozumieć proste informacje przekazane przez znajomych, } \\
\text { np. pocztówkę z wakacji, prostą wiadomość e-mail }\end{array}$ \\
\hline liceum & $\begin{array}{l}\text { - uczeń potrafi rozpoznać ważne informacje (nazwiska, liczby) w prostych } \\
\text { ilustrowanych tekstach oryginalnych o jasnej strukturze, pochodzących np. } \\
\text { z czasopism } \\
\text { - uczeń potrafi zrozumieć prosty prywatny list dotyczący codziennych } \\
\text { spraw } \\
\text { - uczeń potrafi zrozumieć proste informacje przekazane przez kolegów } \\
\text { lub współpracowników, np. dotyczące godziny spotkania, spełnienia } \\
\text { prostej prośby } \\
\text { - uczeń potrafi wyszukać istotne informacje w prostych tekstach } \\
\text { informacyjnych np. broszurach, folderach, ogłoszeniach } \\
\text { - uczeń potrafi zrozumieć prostą ilustrowaną instrukcję obsługi } \\
\text { - uczeń potrafi zrozumieć proste informacje w programach } \\
\text { komputerowych } \\
\text { - uczeń potrafi zrozumieć tekst napisany prostym językiem, dotyczący } \\
\text { codziennych spraw }\end{array}$ \\
\hline
\end{tabular}

Tabela 2: Zakres kompetencji w zakresie czytania.

\subsection{Mówienie, wchodzenie w interakcję}


Podstawowe znaczenie w pracy nad tą sprawnością ma oczywiście zakres posługiwania się mową i umiejętność uczestniczenia w interakcjach werbalnych, prezentowane przez nauczanych uczniów w języku polskim. Praktyka jednak poucza, iż ogromna większość uczniów z uszkodzeniami słuchu podejmuje próby używania języka fonicznego w zakresie języka narodowego. Dzięki rozwojowi technologicznemu (cyfrowe aparaty słuchowe, implanty ślimakowe) i wcześnie podejmowanej terapii (wczesna diagnoza i wczesna interwencja psycho-pedagogiczna) większość uczniów z uszkodzeniami słuchu to nie osoby „głuchonieme”, ale świadomi użytkownicy różnych języków: narodowego, migowego, a także języka angielskiego.

Pracując nad sprawnością słuchania należy uszanować wolę tych uczniów niesłyszących, którzy ze względu na głębokość uszkodzenia słuchu lub przekonania powodujące, iż odmawiają używania języka fonicznego, nie są w stanie opanować podstaw sprawności mówienia w języku obcym. Nawet jednak w przypadku tej grupy uczniów jest prawdopodobne, że mogą oni (np. w czasie pobytu za granicą lub podjęcia kontaktu z użytkownikami języka angielskiego poprzez drogę elektroniczna) stanąć wobec konieczności uczestniczenia w rozmowie prowadzonej w języku angielskim, która może przebiegać np. z wykorzystaniem kartki papieru czy też ekranu telefonu komórkowego lub innych urządzeń, np. i-pod, i-phone itp. Należy także pamiętać, że rozwój technologiczny stwarza coraz to nowe możliwości kontaktu i interakcji i już obecnie dysponujemy możliwościami komunikowania się na odległość poprzez video-spotkania, podczas których możemy widzieć twarz rozmówcy i mówić do niego lub też zapisywać nasze wypowiedzi, które wyświetlane są na ekranie jego monitora (np. program Adobe Conect Pro, Skype, komunikatory internetowe typu Gadu-gadu). W czasie takiej rozmowy konieczne staną się umiejętności rozumienia słownictwa i struktur zazwyczaj stosowanych w rozmowie.

W Tabeli 3 przedstawiono zakres oczekiwanych kompetencji uczniów z uszkodzeniami słuchu w zakresie sprawności mówienia. W przypadku uczniów nie mówiących w języku narodowym należy zadbać, aby także i oni poznali słownictwo i struktury używane w czasie interakcji i umieli je zastosować w formie pisemnej w czasie rozmowy z użytkownikiem języka angielskiego. Zakres oczekiwanych kompetencji na poziomie szkoły podstawowej i gimnazjum mieści się na poziomie językowym A1, licealiści powinni opanować także część kompetencji należących do poziomu A2.

\begin{tabular}{|l|l|}
\hline Typ szkoły & Mówienie - interakcja \\
\hline szkoła & W miarę indywidualnych możliwości związanych z produkcją mowy: \\
& $\begin{array}{l}\text { - uczeń umie przedstawić się (np. I am Kasia) } \\
\text { - uczeń używa w mowie/zapisuje pojedyncze słowa i proste wyrażenia w } \\
\text { języku obcym, np. wyrażenia powitalne i pożegnalne } \\
\text { - uczeń potrafi dokonać prostych zakupów, pomagając sobie wskazywaniem } \\
\text { produktów }\end{array}$ \\
\hline
\end{tabular}




\begin{tabular}{|c|c|}
\hline & $\begin{array}{l}\text { - uczeń świadomie pracuje nad poprawnością swojej wymowy, zwłaszcza w } \\
\text { przypadku zwrotów potrzebnych w codziennej komunikacji (np. zwroty } \\
\text { grzecznościowe, podstawowe pytania, podstawowe informacje o sobie) }\end{array}$ \\
\hline gimnazjum & $\begin{array}{l}\text { W miarę indywidualnych możliwości związanych z produkcją mowy: } \\
\text { - uczeń potrafi zadawać/zapisywać proste pytania, zwłaszcza te dotyczące } \\
\text { jego osoby (np. What's your name?, How old are you?) } \\
\text { - uczeń potrafi odpowiadać/zapisywać odpowiedzi na proste pytania, np. o } \\
\text { czas, cenę, wiek } \\
\text { - uczeń potrafi określać czas, używając określeń takich jak „wczoraj”, „w } \\
\text { następnym tygodniu” } \\
\text { - uczeń umie powiedzieć, że czegoś nie rozumie i poprosić o } \\
\text { powtórzenie/zapisanie informacji } \\
\text { - uczeń świadomie pracuje nad poprawnością swojej wymowy }\end{array}$ \\
\hline liceum & $\begin{array}{l}\text { W miarę indywidualnych możliwości związanych z produkcją mowy: } \\
\text { - uczeń potrafi opowiedzieć o sobie, podać np. adres, wiek } \\
\text { - uczeń potrafi opowiedzieć/przekazać interlokutorowi informacje pisemnie } \\
\text { o swoich zainteresowaniach, swojej rodzinie i miejscu, gdzie mieszka } \\
\text { - uczeń potrafi korzystać z komunikacji publicznej (kupić bilet, dowiedzieć } \\
\text { się podstawowych informacji) } \\
\text { - uczeń potrafi dokonać prostych zakupów w sklepie } \\
\text { - uczeń potrafi zamówić posiłek i napoje } \\
\text { - uczeń potrafi zapytać o drogę i wskazać pytającemu kierunek } \\
\text { - uczeń potrafi zapraszać i reagować na zaproszenia } \\
\text { - uczeń potrafi przeprosić i przyjać przeprosiny } \\
\text { - uczeń umie powiedzieć, co lubi, a czego nie lubi } \\
\text { - uczeń potrafi uzgodnić, co chce robić, dokąd iść } \\
\text { - uczeń potrafi zadawać pytania o to, czym się zajmuje w pracy i czasie } \\
\text { wolnym i odpowiadać na takie pytania } \\
\text { - uczeń potrafi podać krótki opis zdarzeń } \\
\text { - uczeń potrafi opisać swoje hobby } \\
\text { - uczeń potrafi opisać minione czynności i swoje doświadczenie (np. ostatni } \\
\text { weekend) } \\
\text { - uczeń umie poprosić o głos } \\
\text { - uczeń umie okazać, że rozumie lub nie rozumie, o czym mowa } \\
\text { - uczeń umie poprosić o powtórzenie }\end{array}$ \\
\hline
\end{tabular}

Tabela 3: Zakres kompetencji w mówieniu w języku obcym.

\subsection{Pisanie}

Uczniowie z uszkodzeniami słuchu mają szansę, aby w procesie nauki języka obcego osiagnąć umiejętność skutecznego posługiwania się nim w piśmie i mogą tego dokonać w zakresie równym osobom słyszącym. Wyrażanie swoich myśli i opinii w tej formie w pewnym sensie czyni ich w pełni sprawnymi. Wypowiedź pisemna jako taka nie zdradza, czy jej autorem jest osoba sprawna czy też niepełnosprawna, zwłaszcza kiedy podejmujemy kontakt z osobą nam nieznaną, 
np. na forum internetowym czy też w sytuacji pisania formalnego listu do danej instytucji.

Podobnie jak w przypadku mówienia, także sprawność pisemnej ekspresji w języku obcym warunkowana jest, choć w mniejszym niż w przypadku mówienia stopniu, sprawnością posługiwania się językiem narodowym: deficyty w zakresie pisania (np. w zakresie budowania zdań złożonych, stosowania zróżnicowanego słownictwa) w języku polskim przełożą się na trudności w pisaniu tekstów w języku angielskim. Z drugiej jednak strony fakt, że język angielski jest językiem prawie zupełnie pozbawionym złożoności fleksyjnej sprawia, że wielu uczniów niesłyszących twierdzi, iż jest to język dla nich znacznie od polskiego łatwiejszy. Świadczą o tym ich prace (por. DomagałaZyśk 2010b), które spełniaja postulat komunikatywności i w dużej mierze sa poprawne językowo.

W Tabeli 4 zebrano oczekiwane kompetencje uczniów niesłyszących i słabosłyszących w zakresie sprawności pisania w języku angielskim. Sprawności uczniów szkół podstawowych i gimnazjów mieszczą się na poziomie A1, sprawności przypisane licealistom należą do poziomu A1 i A2.

\begin{tabular}{|c|c|}
\hline Typ szkoły & Pisanie \\
\hline Szkoła podstawowa & $\begin{array}{l}\text { - uczeń zna poprawna pisownię poznanych wyrazów } \\
\text { - uczeń uzupełnia zdania odpowiednimi wyrazami } \\
\text { - uczeń zapisuje proste zdania i pytania, zwłaszcza te dotyczące } \\
\text { jego osobiście } \\
\text { - uczeń umie wypełnić prosty formularz wpisując w odpowiednie } \\
\text { miejsca swoje dane (np. wiek, adres, nr telefonu) }\end{array}$ \\
\hline Gimnazjum & $\begin{array}{l}\text { - uczeń pisze proste teksty informacyjne i użytkowe (np. kartkę z } \\
\text { wakacji, życzenia świąteczne) } \\
\text { - uczeń umie napisać prostą notatkę, np. gdzie jest i o której } \\
\text { godzinie chce się spotkać } \\
\text { - uczeń umie opisać w prosty sposób wydarzenia teraźniejsze, } \\
\text { przeszłe i przyszłe }\end{array}$ \\
\hline Liceum & $\begin{array}{l}\text { - uczeń umie napisać proste, krótkie notatki i wiadomości } \\
\text { - potrafi w krótkich zdaniach opisać to, co się wydarzyło } \\
\text { - uczeń potrafi napisać prosty tekst o swoim codziennym życiu } \\
\text { - uczeń umie wypełnić kwestionariusz dotyczący wykształcenia, } \\
\text { zainteresowań, umiejętności } \\
\text { - uczeń umie przedstawić się w liście } \\
\text { - uczeń umie napisać list z pozdrowieniami, zwracając się do } \\
\text { kogoś } \\
\text { - uczeń posługuje się prostymi zdaniami, łącząc je spójnikami „i”, } \\
\text { „ale” }\end{array}$ \\
\hline
\end{tabular}

Tabela 4: Zakres kompetencji w pisaniu w języku obcym.

\section{BIBLIOGRAFIA}


Bavelier, D. 2006. „Do deaf individuals see better?” Trends in Cognitive Sciences, vol. 10/11: 512-518.

Bebko, J. M. 1984. „Memory and rehearsal characteristics of profoundly deaf children" Journal of Experimental Child Psychology 38: 415-428.

Bebko, J. M., McKinnon E. E. (1990). „,The language Experience of Deaf Children: Its Relation to Spontaneous Rehearsal in a Memory Task". Child Development 61: 1744-1752.

Centralna Komisja Egzaminacyjna. 2003. Informator maturalny dla osób niesłyszacych. Warszawa: CKE.

Deleżyńska, K. 2009. Testy maturalne z.jezyka angielskiego dla ucznia niestyszqcego. Wskazówki dla nauczyciela $i$ dla ucznia. Warszawa: Centralny Óśrodek Doskonalenia Nauczycieli.

Domagała-Zyśk, E. 2006. „Edukacyjne i terapeutyczne wartości lektoratu języka angielskiego dla studentów niesłyszących”. w: K. Krakowiak, A. DziurdaMultan (red.) Przekraczanie barier w wychowaniu osób z uszkodzeniami stuchu. Lublin: Wydawnictwo KUL. 423-432.

Domagała-Zyśk, E. 2009a. Trudności osób niesłyszących w nabywaniu słownictwa w języku obcym i sposoby przezwyciężania tych trudności. w: M. Dycht, L. Marszałek Dylematy (niepetno)sprawności - rozważania na marginesie studiów kulturowo-społecznych. Warszawa: Wydawnictwo Salezjańskie. 223-236.

Domagała-Zyśk E. 2009b. „Lekcje i zajęcia języka obcego dla uczniów niepełnosprawnych". w: H. Komorowska (red.) Skuteczna nauka jezyka obcego. Struktura i przebieg zajé́ jezylkowych. Warszawa: Wydawnictwo CODN. 232-246.

Domagała-Zyśk, E. 2010. Procesy pamięciowe u osób z uszkodzeniami słuchu a nauczanie ich języka obcego. w: M. Wójcik (red.). Edukacja i rehabilitacji osób ₹ wada stuchu - wyzunania wspótçesności. Toruń: Wydawnictwo Edukacyjne „AKAPIT”. 119-130.

Domagała-Zyśk, E. 2010a (maszynopis w druku). Specyficzne trudności osób niesłyszących w zakresie opanowania pisemnej formy języka obcego i możliwości kompensowania tych trudności.

Domagała-Zyśk, E. 2010b (maszynopis w druku). Uwarunkowania rozumienia tekstu w języku obcym przez osoby z uszkodzeniem słuchu.

Domagała-Zyśk, E. 2010c (maszynopis w druku). Kompetencje wzrokowe osób niesłyszących i możliwości ich wykorzystania w zakresie nauczania języków obcych.

Domagała-Zyśk, E. 2010d. (maszynopis w druku). Style uczenia się preferowane przez niesłyszących uczestników lektoratu języka obcego.

Domagała-Zyśk E. 2010f. (maszynopis w druku). Poziom motywacji niesłyszących studentów do uczenia się języków obcych.

Domagała-Zyśk, E. i A. Podlewska. 2010e. (maszynopis w druku). Umiejętności polskich studentów z uszkodzeniami słuchu w zakresie posługiwania się mówioną formą języka angielskiego. 
Europejskie Portfolio Jesykeowe (2005). Warszawa: CODN. ISBN 83-87958-66-2.

Harmer, J. 1991. The Practice of English Language Teaching. London \& New York: Longman.

Heiling, K. 1995. The development of deaf children. Academic achievement levels and social processes. Hamburg: Signum.

Krakowiak, K. 2003. Szkice o uychowaniu dzieci z us₹kodzeniami stuchu. Stalowa Wola: Oficyna Wydawnicza Fundacji Uniwersyteckiej.

Leybaert, J. 1993. „Reading in the deaf: the role of phonological codes”. w: Marschark M., Clark D. (red.) Psychological perspective on deafness. Hillsdale: Lawrence Earlbaum 269-309.

MacSweeney, M. 1998. „Cognition and Deafness”. w: Gregory S., Knight P., McCraken W., Powers S., Watson L. Issues in Deaf Education. London: David Fulton Publishers.

Marschark, M., Lang H. G. \& J. A. Albertini. 2002. Educating deaf students. From research to practice. Oxford: Oxford University Press.

Marschark, M. 1998. „Memory for language in Deaf Adults and Children”. Scandinavian Audiology 27 Supl. 49: 87-92.

Parasnis, I. 1998. "Cognitive Diversity in Deaf People: Implications for Communication and Education". Scandinavian Audiology 27. 49: 109-115.

Parasnis, I., Samar, V. J., Bettger J. G., \& K. Sathe. 1996. «Does deafness lead to enhancement of visual-spatial cognition in children? Negative evidence from deaf non-signers ». Journal of Deaf Studies and Deaf Education 1. 145-152.

Prillwitz, S. 1996. Jezy) k, komunikacja i zdolności poznawcze niestyszacych. Warszawa: WSIP.

Rettenbach, R., Diller, G. \& R. Sireteanu. 1999. «Do deaf people see better? Texture segmentation and visual search compensate in adult but not in juvenile subjects ». Journal of Cognitive Neuroscience, 11. 5: 560-583.

Samar, V. J., Parasnis I. \& G. Berent. 1998. «Learning disabilities, attention deficit disorders and deafness «. w: Marschark M., Clark D. (red.) Psychological perspectives on deafness, tom II. Hillsdale, NJ: Lawrence Erlbaum.

Stachyra, J. 2001. Zdolności poznawcze i możliwości umystowe uczniów z. uszkodzonym stuchem. Lublin: Wydawnictwo UMCS. 